\title{
Decline in academe $e^{1,2}$
}

\section{QIJEI}

International

Journal for

Educational Integrity

\author{
Kim R. Sawyer \\ Honorary Fellow, School of Philosophy, Anthropology and Social Inquiry, \\ University of Melbourne \\ kim.sawyer@unimelb.edu.au
}

Jackie Johnson

Retired, Accounting and Finance, University of Western Australia

jak_j@yahoo.com

\section{Mark Holub}

Accounting and Finance, University of Western Australia

mark.holub@uwa.edu.au

Keywords: Academic, corporatisation, institutional change, managerialism, organisational change, university

\begin{abstract}
When universities became corporate universities, the constraints that defined universities changed. The values of the old university, of scholarship, truth and freedom, were replaced by the values of the market. Education became a product, the university a firm, and the university system an industry. This paper considers the decline in academe as universities converge towards for-profit corporate universities. The paper explores why universities have become corporations, how they have become corporations, and how academics survive within those corporations. In the corporate university, the academic becomes accountable to management and to students. Collegiality is sacrificed for managerialism, and freedom for accountability. The academic role is inverted. The academic becomes the academic of the production line, producing standardised teaching and research. The paper suggests that the corporate university risks sacrificing too much scholarship and too much freedom for the principles of the market, thereby diluting the integrity of the university.

"On his way to the Ministry, the Minister learns that there is a new hospital in Northern London that is staffed with 500 administrators and ancillary workers, but has no doctors, nurses or patients. The Minister is aghast."

From The Compassionate Society. Yes Minister, BBC (1981).
\end{abstract}

\section{Introduction and institutional theory}

North (1990) defined institutions as the constraints which shape human interaction. The constraints may be formal, for example the listing requirements of a company on the stock exchange, or informal such as the codes of research conduct in universities. The constraints which define an institution are designed to reduce uncertainty by creating stable structures. The institutional dividend is therefore the reduction in economic and social risk. When institutions change, constraints change, and

The International Journal for Educational Integrity is available online at: http:// www.ojs.unisa.edu.au/journals/index.php/IJEI/ 
economic and social risks change. This paper concerns one of the most important institutional changes of our lifetime, the corporatisation of universities.

Most institutional change is incremental, and the consequent changes in constraints and individual interactions are also incremental. But, for universities, institutional change has been catastrophic rather than incremental. In some countries, the constraints which defined universities for centuries were rendered meaningless. In the United Kingdom (UK), the 1991 White Paper ${ }^{3}$ on higher education granted university status to most non-university institutions. In Australia, the 1988 White $\mathrm{Paper}^{4}$ established a unified national system which conferred university status on nonuniversity institutions. In both countries, the concept of a university has been redefined. ${ }^{5}$

However, White Papers alone did not redefine the universities. Most national governments began pursuing the simultaneous objectives of educating a higher proportion of the population to a higher level, and of reducing the dependence of universities on government funding. These simultaneous objectives implied that higher education, previously differentiated and exclusive, became standardised and open to a mass market. Universities responded by becoming revenue maximisers, enrolling more students and levying higher fees. Higher education became an industry and universities became producers competing with other producers in a global market. The old universities became new corporate universities.

In this paper, we consider an analysis of the role of the academic as universities converge towards corporations. The use of a binary classification of the old university and the new university simplifies this analysis. No university is either exclusively old or new. Many universities adopted corporate structures in commercialising their research many years ago; for example, Massachusetts Institute of Technology established an office of corporate relations in the 1930s to permit collaboration between corporations and academics. Conversely, most universities retain some form of the collegiate old university, at least in their faculty and departmental structures. Other authors use a multivariate classification. McNay (1995) considered four types of university: the old collegiate university, the bureaucratic university, the corporate university and the enterprise university. Lewis, Marginson and Snyder (2005) suggested that the new corporate university is a hybrid of bureaucratic, corporate and enterprise models. The binary classification into old and new confers one particular advantage. In the modern university, the old and new co-exist and are often incompatible. Indeed, the story of the convergence from the old collegiate university to the new corporate university is principally a story of how academics have responded to the incommensurability between the two structures. This incommensurability has stimulated many papers, for example Lewis, Marginson and Snyder (2005), a number of public inquiries, for example, the 2001 Australian Senate Inquiry into Higher Education and, more generally, a questioning of the enterprise university. ${ }^{6}$ And this incommensurability has also underscored the observations and reflections of the present paper.

The constraints which defined the old university and now define the new university are so markedly different that human interactions within universities have changed. The old university was characterised by a commitment to a set of intangible values of scholarship, truth and freedom and were sanctuaries of freedom. The University of Cambridge amplifies the point, its core values being 'freedom of thought and expression' and 'freedom from discrimination'.7 The mottos of most universities reflect this commitment to intangible values; the common factor being the search for truth and a higher order of knowledge. ${ }^{8}$

The intangible values which defined the old university were typically not measurable. Most were relative, rather than absolute. Freedom for one individual often represented restriction for another. The intangible values were not tradable in a marketplace. Scholarship, truth and freedom may have a price, but the price is best 
realised when they are gone. If the old university was a marketplace, it was a marketplace of ideas. Ideas were the currency of the old university. Ideas determined reputations and resource allocations. It was therefore appropriate that Berkeley, who refined the concept of an idea more than any other individual, should be so honoured with the naming of a university. Interaction of academics in the old university was based on the interaction of ideas. The stability of the institution depended on these interactions being free and fair. The institution minimised uncertainty by insuring its ideas and its scholarship. Of course, financial risks were not negligible; the university required funding. But it was the risk associated with scholarship that was the principal risk of the university.

The old university was a centre of learning, not training. Its assets were intellectual, not physical, its balance sheet was intellectual, not financial, its return was the return on ideas, not the return on assets, and its language was the language of ideas, not the language of management. The principle of the old university is well captured by the reflection of the Yale University librarian more than 75 years ago who, when observing the magnificence of the new library, proposed that the motto "This is not the Yale Library. That is inside." be carved over the main entrance. ${ }^{9}$ The librarian's reflection, of course, has a wider generality. The value of a university is its intrinsic value, not the value of its physical assets.

The old university was characterised by discretion and differentiation. Failure rates were at the discretion of the academic rather than a bell curve, curricula were the province of the academic rather than online textbooks, matters of right and wrong were determined by the academic rather than a code of ethics, and governance was determined by the collective discretion of the academics rather than a by a chief executive officer and a board of external directors. As a consequence, a course in biology at the University of Chicago was significantly different from a course in biology at the University of Sydney, and it was this differentiation that defined the universities. But, typically, no student would test this difference. There was little student mobility. If there were a market for students, it was a local market.

But the old university had become inflexible. It was unresponsive to government needs to educate more students to higher levels; it was slow in responding to the demands of students for market-related courses, and its decision-making had become unaccountable in an era when accountability mattered. It was the unaccountability of the old university which almost certainly determined its dissolution. The constraints which defined the old university had established hierarchies inconsistent with the hierarchy of corporations. Top-down accountability was absent, the role of stakeholders was poorly defined, and the performance of the university was often unmeasurable. The legislators who reformed universities observed the unaccountability of the old university, and were determined to change it. The old university was transformed into a corporation competing against other universities, but with a special accountability to government and to other stakeholders.

When universities became corporations, the defining attributes of the old university were subordinated. The new constraints, which defined the institution, were the constraints of the market. It was market signals that were priced, not scholarship. Universities began to behave like firms with no shareholders, operating with a declining government subsidy, and trying to maximise sales in a market with excess demand. Student demand was paramount, and the determinants of demand became the determinants of the university. The constraints, which shaped the university, were now the number of students enrolled, the fees that were charged, the students' ability to pay, the efficiency of the service and the quality of the product. Universities were competitors, competing on the basis of a quality-adjusted price. In terms of North's (1990) theory of institutions, institutional change meant that universities were now conditioned by monetary values rather than intangible values. ${ }^{10}$ Institutional change was most costly when the divergence between these values was large. Institutional 
change was least costly when the intangible values had never existed, except on the crest of the university.

When institutions change, human interactions change. For the academic, the relevant interactions within a university are with students, administrators, management and other academics. When an institution behaves like a firm, these interactions assume a form of implicit contract. The modern theory of the firm maintains that a firm consists of a set of implicit contracts, which determine how the firm behaves (Zingales, 2000). For a university, the implicit contracts are defined by a set of implicit terms and conditions; for example, when an academic teaches a student, they must assess that student without fear or favour. The decline in academe can be attributed to the decline in terms and conditions of the contracts between academics and their counterparties: students; administrators and management; and their fellow academics.

The academic contract with students changed appreciably with the corporate university for two main reasons. First, education is now a product and it is an increasingly standardised product. Standardisation is one of the most important principles governing higher education. Standardisation refers to the convergence of curricula, textbooks, technology, assessment procedures, failure rates and academic decision-making. Standardisation occurs both within and across universities. The effect of standardisation is to reduce the discretionary authority of the academic. The academic becomes little more than a cardboard cut-out. The second reason relates to the student as a customer. The management of universities empowered the student through student evaluations, through standardised failure rates and grade distributions and, more generally, through the notion that the fee payer is entitled to a service, rather than the joint determination of their education. Student evaluations, which were introduced as a benign measure of course content, are now used as a measure of the academic. With standardisation and with the student as the customer, the implicit contract of the academic and the student inverted. Academics became accountable to the students.

The academic contract with administrators also changed with the corporate university. The explosive growth in student numbers, particularly in the business faculty of universities ${ }^{11}$, meant that the scale and scope of administrative tasks for many courses and disciplines increased. The academic response was to subcontract tasks to administrators. As subcontracting increased, administrators assumed the role of decision-makers. Administrators became better informed than academics about procedures and information within the university, extracting monopoly rents from their decision-making. With more students, more information and more procedures, the administrative role became super ordinate. And, more administrators were then required. For example, in the G8 grouping of the leading Australian universities ${ }^{12}$, there are now at least 1.3 administrators for every academic. ${ }^{13}$ This suggests that the product of universities is no longer just education, but also administration. As with the contract with the student, the implicit contract between the academic and the administrator inverted. Academics became accountable to the administrators.

While the inversions between academics and students, and academics and administrators are important, it is the contract between academics and management that has generated the most comment (Dobson, 2000; Anderson, Johnson, \& Saha, 2002). When academics speak out, they speak out principally about management, and principally to reinforce the values of the past ${ }^{14}$ - scholarship, truth and freedom (Bessant, 1995; Parker \& Jary, 1995). If the management of a corporate university seeks wisdom, it is usually the wisdom of minimising risk. Financial risk is the most important risk for a university behaving like a firm. All universities are concerned with shortfalls in revenue because, typically, the shortfall can not be recovered through government subsidy. Scholarship matters, but only to the extent that it correlates with revenue. There is a complex trade-off between scholarship and revenue. 
Scholarship is a determinant of student demand, but if the standards are too high, students are deterred. Universities usually solve this problem by segmenting research and teaching. Research reputation is maximised but, for teaching, student satisfaction is maximised. The standards in the classroom must exceed some minimal value, but they cannot exceed some maximum value. Academics committed to scholarship must recognise that scholarship is bounded.

For management, the academics who speak out about a decline in their standing are a risk to the university's reputation. It is true that reputations change slowly and usually depend on the values established by the old universities. It is rare, for example, for Harvard or Oxford to be omitted from any ranking of the top five universities in the world. Reputations also change through competition, which allows research teams to migrate between universities. But reputations can also change through disclosures and the management of most universities regard unauthorised disclosures as contrary to the reputation of the university. An academic committed to freedom of thought and expression has to exercise those freedoms with discretion.

The risks associated with scholarship and disclosures have been amplified by the imposition of line management on a collegial system. Line management has had important consequences. First, it has caused a separation between management and academia. The academic produces the product and management insures the product on behalf of the student. Few senior managers of the corporate university have taught in a classroom, supervised a research student or marked an exam paper in their most recent history. Few academics know of the information which underwrites management decisions. There is now a substantial information asymmetry between management and academics. Secondly, positions which were once rotational positions are now a rung on the line management ladder. Heads become Deans, and then Pro-Vice-Chancellors, Deputy Vice-Chancellors and Vice-Chancellors. They rarely return to academia. There are now two types of academics: those who pursue management and forego teaching and research; and those who continue to teach and to research. The values of the former tend to reflect the monetary values of the corporate university; the values of the latter the values of the old university. Thirdly, management and academics have different sets of accountability. While the performance of academics is increasingly measured in terms of student evaluations and number of research publications, there is no comparable measurement of management performance. Significant management failures are written off as the risks of entrepreneurship. Academics and the management they underwrite have diverged.

The implicit contract between academics and other parties (students, administrators and management) has been rewritten in favour of the counterparties. The response of academics has been to rewrite the contracts between themselves. The academics who comprise a corporate university are now like a set of firms, competing in terms of research, contracting in terms of teaching in a joint production function, and segmenting into two markets, the academic market and the management market. The concept of collegiality has been superseded by collusive competition; this suits management. It enhances the probability of individual contracting, it minimises disclosure, and it empowers management.

In synopsis, North's (1990) theory of institutions implies that when universities became corporations, the constraints which defined them changed. The constraining values of scholarship, truth and freedom were replaced by market constraints. Necessarily, the interactions between academics and other parties, which Zingales (2000) refers to as implicit contracts, changed. Academics became more accountable to students, administrators and management. Their contracts with counterparties were rewritten. Their standing declined. In the remainder of this paper, we consider the decline of the academic in more detail. In Section 2, we consider the traditional role of the academic. In Section 3, we consider the corporate university and in 
Section 4 the role of the academic in the corporate university. Section 5 concludes the paper.

\section{The academic}

In Greek mythology, academia was the orange grove where Akademos revealed the presence of Helen of Troy to her brothers. As a result, the Gods enshrined academia as a place where fundamental truths would be revealed. It is where Plato conversed with his followers, establishing a tradition of perpetual inquiry. It is this tradition which defines the term academic, not as a term of irrelevance, but as a term of purpose.

But it is a purpose in decline.

The university as a modern institution was formed in the middle ages. Medieval universities were not physical locations. They were congregations of individuals who gathered together in places where they were able to teach. Support came in a variety of forms. In some cases students hired and paid for their teachers, in other cases teachers were paid by the church, providing the foundation of the university as an eleemosynary institution. Oxford and Cambridge universities, the oldest universities in the English speaking world, were predominantly supported by the crown and the state. Who financed the university usually determined who governed the university, a principle not lost on the management of corporate universities.

Universities flourished during the Enlightenment in the 17th and 18th centuries when revolutionary ideas in art, philosophy and politics developed. The universities which generated many of the ideas were the old universities in Bologna, Oxford, Cambridge and Paris where a guild of scholars was distributed among the faculties of arts, science, medicine, law and theology. It was the period when the universities evolved, and their evolution underscored academic ideals.

The writings of John Henry Newman, a leader in the Oxford Movement, became pivotal in redefining the ideals of the academic. Newman's ideal for universities was that they should be "communities of learning devoted to the pursuit of significant truth, as an end in itself, and, as such, fulfilling a central cultural and ethical role for society at large". And Newman's ideal for the university-educated person involved cultivation of the intellect, which went beyond "mere knowledge of items of fact, mere acquisition of information, or bare proficiency at such intellectual skills ... as the professions may require". Newman emphasised "depth and integrated perspective, and the accompanying intellectual virtues of honesty, intellectual courtesy, indifference to mere fashion in ideas, and a dedication to the regulative ideal of truth". ${ }^{15}$ The ideals of Newman are the ideals to which most academics subscribe in the abstract. They are also the ideals which are most violated in the particular.

Newman's significant truth can only be pursued when a set of conditions is met. These are the conditions which underscore free inquiry. They relate to the uncertainty of truth, the significance of truth, the integration of truth, the irrelevance of time and the importance of freedom. When these conditions are weakened, the pursuit of significant truth is weakened. The corporate university has weakened these conditions.

In the pursuit of truth, the relevant uncertainty is uncertainty about the truth, not uncertainty about the consequences of the truth. Truth should be priced at a premium, not a discount, and any caveats should relate to the uncertainty of the underlying assumptions, not the fear or the favour that truth generates.

Independence is critical; uncertainty in findings must not be correlated with the researcher. When a researcher is paid by a corporation to investigate the possibility of the corporation's emissions causing cancer, the dependence of the researcher on the corporation weakens the findings. In the old university, financial independence 
meant that the truth was independently pursued. In the corporate university, financial dependence means that truth is often not independently pursued. There is no better test than when the corporate university inquires into itself. The internal inquiries of the corporate universities have shown how truth can be discounted, for example, the Hall case at the University of New South Wales. ${ }^{16}$ If a university can not inquire into itself, it can not inquire into anything.

The pursuit of the truth also requires an understanding of significance. Significance in the Enlightenment period connoted more than statistical significance; it often related to questions concerning a higher order of meaning. Significance became the significance of the unknown as well as the known. In the modern university, significant incrementalism has replaced significant truth. Finding hypothesis probability values less than $5 \%$ has replaced insight. As a consequence, questions about a higher order are never asked. And the unknown is priced to zero. The debate of God versus Science, the critical debate of the Enlightenment, rarely appears in corporate universities, but often appears outside the university. ${ }^{17}$ This separation between questions of real significance and questions of incremental significance weakens the meaning of significance. The significance of significance has declined.

Truth can not be segmented, it is integrated. The truths in physics are not dissimilar from the truths in economics; the truths in corporate finance are not dissimilar from the truths in behavioural finance. The truths in research are also not dissimilar from the truths in teaching and administration. The integration of truth is important to its pursuit. This is recognised in the establishment of interdisciplinary research centres such as the Warren Centre at the University of Sydney and the Center for Complexity at the University of Illinois. But, when an academic is segmented into a person who is required to pursue truth in research, but not necessarily in teaching and administration, the academic ceases to be an academic. The old university unified the academic, across disciplines and across research, teaching and administration. The corporate university segments the academic. The resulting loss is the loss in truth.

In the pursuit of truth, time is irrelevant. Darwin took twenty years to publish The Origin of the Species; Einstein's Theory of Relativity was produced in one year and was only five pages long; Thomas Bayes, the founder of Bayesian statistics, never published in his lifetime. In the old university, time was not relevant to the pursuit of truth; tenure protected the academic and protected the pursuit of the truth. The old university recognised that the pursuit of truth is not linear, not immediate and not a production line. The old university recognised that the great questions of the 17th century would still be the great questions of the 21 st century. The corporate university assumes that time matters and that truth is linear in time. The academic producing 30 papers a year is considered 30 times more productive than the academic producing one paper. But, as Einstein showed, one paper can rewrite a thousand others.

Finally, the pursuit of truth depends on the freedom to conceive ideas, express ideas and interact with ideas, without institutional restriction. Freedom requires the unconstrained investigation of all data without first proving its need. Freedom is crowded out when the academic role is too prescribed, or when the academic becomes too accountable to counterparties. The corporate university circumscribes the truth because it circumscribes freedom. The corporate university must manage the trade-off between academic freedom and academic accountability. Like the firm optimising its debt-equity ratio, the corporate university must optimise its freedom/ accountability ratio. Too much freedom destroys efficiency, but too little freedom destroys the truth. The risk is that corporate universities have traded-off freedom too far. 


\section{The corporate university}

To understand the corporate universities in which they work, academics need to understand the evolution of the corporate university; in particular, why universities became corporations, how they became corporations, how they restructure, and how their structure explains their conduct. The corporate university is not simply a corporation; it is typically a laboratory of restructuring, where mergers, spin-offs, privatisations, and internal restructuring are common. The academic is the subject of the restructuring and, just as corporate restructuring in general is more likely to destroy value than create value, so university restructuring has often destroyed value for the academic.

\section{How universities became corporations}

Universities became corporations because of the government objective to educate, with minimum subsidy, more students to higher levels. They also became corporations to fulfil another economic imperative, namely to act as a store of value of past knowledge and to produce generations of future knowledge. This was particularly so in the United States (US) where research and development universities had been fundamental to the research of the military, industrial and entertainment complex for more than a century (Bishop, 2006). Thus, universities were corporatised not only to make them more accountable, they were also corporatised to underpin the macro economy.

All universities faced the same financial constraints, but different universities pursued different paths towards the corporate university. The polytechnics of the UK and the technical colleges of Australia had always behaved like corporations; their tradition was in training students for the workplace rather than for life, and they had often commercialised their research. When the technical colleges became universities, they responded quickly to the demands of the market. They were the first to compete for international students and they were the first to restructure. Their path to the corporate university was relatively costless. They had priced intangible values such as scholarship lower than the old universities.

For the old universities, the transition to a corporate university often came with significant cost. There were many possible paths to becoming corporate: Melbourne University Private, a private subsidiary of Melbourne University was created by an act of the Victorian Parliament ${ }^{18}$; and Melbourne IT, a commercial spin-off of Melbourne University was created through a public listing on the stock exchange. Privatisations and spin-offs represent the transparent corporate takeovers of academe. But there have also been corporate takeovers by stealth. Commonly, this occurs by appointing external non-academics to govern and manage universities; for example, as members of university councils, as executive deans and as directors on Faculty boards. The appointment of non-academics to govern and manage universities is a statement that the university is like any other firm, and that it can be taken over and restructured like any other firm. Non-academics typically have the values of the market; they are asset managers rather than ideas managers, their capital is physical not intellectual and, apodictically, they appoint their own. For the new entrepreneurs of academe, a worldclass business school is built by building a worldclass building, not a worldclass intellect. ${ }^{19}$ For these entrepreneurs, intellectual capital is like any other asset; it can always be purchased rather than nurtured. The risk is that the intellectual capital may never be realised, in which case the building is valueless.

Most often, the old universities became corporations through competition; they had to compete for students to survive and in competing they became like corporations. However, universities are not typical firms. As Winston (1997) recognised, universities and for-profit firms are different. Universities are revenue maximisers, not profit maximisers. Universities do not distribute their profits to shareholders, or to any 
stakeholders. In many ways, corporate universities are like stock exchanges. They seek to maximise fee income just as exchanges maximise fee income, they rely on the home bias of students just as exchanges rely on the home bias of investors, and they form strategic alliances across countries just as exchanges form strategic alliances across markets. But, unlike stock exchanges, universities operate with a subsidy both from government and from philanthropists; student fees rarely cover their costs. Universities can afford to operate inefficiently provided the inefficiencies are not disclosed. And they seldom are.

Universities have become corporations through privatisations and spin-offs, through the appointment of non-academics, and through competition. However, the evolution of the corporate university is not yet complete. The corporate university, while not-forprofit, is slowly converging to the for-profit firm. The most corporate of the corporate universities is the University of Phoenix, founded in 1976 as a for-profit university. ${ }^{20} \mathrm{It}$ is a subsidiary of the Apollo Group, which is listed on the New York Stock Exchange. This is the model to which many universities are converging, where education is a standardised product offered online across hundreds of campuses to hundreds of thousands of students, and where the academic is virtual, rather than real. The share price of the Apollo Group is the market's price of their scholarship. Most corporate universities are borrowing elements of the Apollo model; for example a group of 20 old universities formed a university cartel Universitas 21 , based in Singapore, which delivers a standardised MBA online to students in 12 countries. The evolution of the old university to the not-for-profit corporate university and then to the for-profit corporate university is now well defined. As universities become more dependent on self-financing, it is now possible that they will issue securities and list on the stock exchange. The corporate university will then be complete, and market equity will have replaced academic equity.

\section{The academic response}

The common response of academics to corporate takeovers has been rejection, but rejecting in silence. This benign response has been attributed to the risk aversion of academics, their legitimate fears of job security, their acceptance of the foreshadowed efficiency benefits and, in some cases, their expectation that the corporate experiment would fail without any cost to them (Biggs, 2002; Davis, 2002). It is doubtful if academics foresaw the change in their position, from intellectual capital to labour that their decision foreshadowed. Interestingly, neither Australian academics, nor their Vice-Chancellors, nor the community they educated, responded to the funding cuts which preceded the Australian reforms. ${ }^{21}$ This reinforced the resolve of the Australian government to pursue the reforms (Davis, 2002). Corporate reform requires compliance.

Unlike the shareholders of a firm, academics have rarely voted on their takeovers. When they have been able to vote, they have often rejected the corporate takeover. In 2006, a strong test of the corporate university occurred at the oldest university, Oxford. After two years of discussions, Oxford dons had to vote on reforms, which would have made Oxford a corporate university. Under the reforms, a new academic board was to be created to administer the institution's teaching, research and policy, while a reduced academic council with seven university members and seven external business members, would oversee the University's finances and its legal compliance. Those who supported the reforms argued for efficiency of management and governance ${ }^{22}$ a standard argument of the proponents of the corporate university. Efficiency usually connotes the speed and unanimity of decision-making; smaller governing bodies make decisions faster and with less dissent. Decisions are typically biased towards strategies, which generate short-term financial returns, and not longterm non-financial returns. Without dissent, decisions are made quickly, but the risk is that the cumulative wisdom of the university is ignored. The cumulative wisdom of Oxford, however, was that the reforms were not necessary. The Oxford dons voted to reject the reforms. They apparently preferred their old wisdom to the new efficiency. ${ }^{23}$ 


\section{Structure}

When a university becomes a corporate university, the language of the market replaces the language of learning; the university becomes a firm, the university system becomes an industry, education becomes a product, and the academic is homogenised. But, the university system is not a typical industry. In most countries, it is a set of competitors who compete using their brand names. The industry is both a strategic national industry, satisfying domestic students and an export industry competing for international students. ${ }^{24}$ Education may be sold as a product for immediate consumption but it should be designed as a lifetime good which bestows an annuity on the student.

Corporate universities compete by producing a homogeneous undergraduate product. Homogeneity in undergraduate programs is important because students compete for similar jobs in similar markets. Necessarily, a macroeconomics course at the University of Western Australia can not be too different from a macroeconomics course at the University of Manchester. Homogeneity means that curricula, the length of courses, the length of exams, the exam questions, the assignment questions, the teaching technologies and the textbooks must be standardised. Universities and, by implication, their academics have limited discretion. Competition between firms within an industry reduces the discretionary role of the academic.

For academics, industry structure matters, but it is the university's structure that matters most. In the corporate university, the CEO has a vision, the university a mission statement, the Faculty a strategic plan, and the department an operational plan. When the corporate university restructures, the vision changes, the mission statement changes, the strategic plan changes, and the operational plan changes. Restructuring has had three principal effects: the imposition of managerialism; the decline of collegiality; and an increase in uncertainty. Managerialism in general refers to two principles, top-down management and bottom-line accounting. It implies that decisions in a university conform to management objectives, that members of the university are accountable according to a hierarchy of supervisor and supervisee, and that the risks of an individual become the risks of the university. The problem is that the academics and managerialism do not usually conform.

Managerialism typically circumscribes the important decisions of the university in the hands of a group of administrators who reside in the inner quadrangle of the university. They are the visionaries of the university who rarely have time to enter the classroom. They appoint their own, rarely disclose, and are not subject to student evaluations. When a new CEO is appointed, after an extensive search, it is often the person in the next office, or in the next university. The members of the inner quadrangle are the real beneficiaries of the corporate university.

The managerialism imposed on universities is not dissimilar to the textbook model of managerialism advanced in the theories of organisational development of the 1970s. As Parker and Jary (1995, p. 325) note:

These ideas have been used both to enhance the importance of management as a process within the institution and also to legitimate the activities of particular members - executives, directors and so on - as key decision makers. As with other UK public sector organizations, the dull but worthy 'administrator' who supported the professional becomes the dynamic leader-manager who directs and inspires other professionals.

Managerialism is a blunt instrument. It does not adjust for the history or culture of the university, nor the role of the academic. The underlying assumption is that the managerialism of the non-university firm is appropriate for the university. However, at 
the time managerialism was being introduced into the universities, Willmott (1995) notes that it was already out of favour in the corporate world.

A number of authors have identified the incompatibility of managerialism with the innovation of universities (see, for example, Biggs (2002)). The constraints of managerialism promote incrementalism, not innovation. Managerialism prescribes the professor. The professor can teach, research and think, but only within the bounds prescribed by management. The professor must become linear - linear in time, linear in thinking, and linear in research output; in sum, a linear production line. There is no place for an Archimedes, working for twenty years without return, and exclaiming "Eureka, l've found it" at the end. Managerialism does not price the longterm, and it doesn't price serendipity.

The trade-off between academic accountability and academic freedom, identified in Section 2, in practice becomes a trade-off between managerialism and innovation. Many high technology companies, for example Google and Intel, have recognised the risks of managerialism, preferring to adopt flat and unconstrained management structures. A free structure, unconstrained by the prescription of a supervisor and supervisee, promotes freedom of thought and expression. Freedom promotes thinking, because it permits thinking outside the quadrangle. And it is thinking outside the quadrangle that shifts paradigms. Under managerialism, paradigms do not shift, because thinking is constrained. These constraints ensure that managerialism survives.

The restructuring of universities has elevated managerialism; simultaneously it has diminished collegiality. Collegiality is the structure of the old university, of the 39 colleges of Oxford University and of the congregations of scholars that preceded Newman. Collegiality assigns importance to every academic, not just those who reside in the inner quadrangle of the university. Collegiality is underwritten by the values of the old university. It does not codify rules and procedures; rather it relies on the collective wisdom accumulated through the failures and successes of the past. Failure is important in the collegiate system, because it provides lessons for the future; for example, the student Honour Court system used to discipline students in more than 100 US universities originated because of the failure to properly discipline students at the University of Virginia in 1840 . Collegiality was the principle which determined the votes of the 730 Oxford dons who voted against reforming their governance system in November 2006. Most academics value collegiality.

But collegiality has risks: the risk that decisions take too long; the risk of no accountability; and the risk of dissent. Managerialism was imposed to reduce these risks, and it succeeded. With managerialism, collegiality dissolved. Managerialism and collegiality are negatively correlated. Managerialism is underscored by hierarchy, collegiality by lack of hierarchy; managerialism writes off failure, collegiality learns from failure; managerialism codifies behaviour, collegiality accepts behaviour. For many academics, managerialism represented control, not only of their thinking, but also of their collegiality. The corporate university reduced the risks in decisions by purging collegiality. Concomitantly, the value of the academic declined.

The corporate university has altered the balance between managerialism and collegiality. Through restructuring, it has also increased uncertainty. Restructuring has admitted many variations; faculties have merged into divisions; been replaced by portfolios; been split into their previous constituent parts. Departments have been amalgamated into schools; been abolished to become disciplines; moved into other faculties. Divisions have become faculties; schools have been merged. There are an infinite number of possible structures, and some universities are testing them all. Uncertainty in the structure has increased uncertainty for the academic. This uncertainty has been compounded by uncertainty associated with student demand. The closure of the Physics Department at Reading University is an example of short- 
term student demand overwriting long-term academic values. Despite calls from the UK's Institute of Physics not to close the Department, the Vice-Chancellor of Reading, Prof Gordon Marshall, said higher costs meant it could not continue to subsidise the loss-making department. ${ }^{25}$ Uncertainty, whether attributable to restructuring or to student demand, increases the risk for academics and, as they are typically risk averse, their response has been to fragment and to obey. Uncertainty controls academics, just as managerialism controls them.

Industry structure, university structures and university restructuring have all contributed to a decline in the value of the academic. Through competition, the discretionary role of the academic has declined. Through managerialism, their collegiality has declined. And through restructuring, their uncertainty has increased. This is the decline in academe.

\section{Control}

When a firm takes over another firm, control passes to the shareholders of the bidding firm. In the corporate takeover of the universities, control passed to various stakeholders, principally the CEO and senior management, members of the governing body, and students. Academics are now the minority stakeholders. Sometimes they are not stakeholders at all. In 1992, for example, RMIT was created as an Australian university by an act of the Victorian Parliament. In the RMIT Act, the University was defined as "a body politic and corporate consisting of a Council, the enrolled students and members of the academic, teaching and other staff prescribed by statute." ${ }^{26} \mathrm{It}$ then took more than three years for RMIT to prescribe a statute conferring membership of the university to the staff. During this period, the University consisted only of a Council and students.

The CEO and senior management determine the direction of the university, its vision, its mission statements, its strategic and operational plans, and its structure. They exercise control over academics. The members of the governing body are typically chosen to minimise their divergence with the CEO, that is, to minimise risk. For the CEO, the optimal appointment to the university council is an external businessperson with a commitment to market values, with no knowledge of academia, and who regards the appointment as an honour rather than a job. This is exemplified by the UK's Committee of University Chairmen's guide for universities ${ }^{27}$ which emphasises that the councils of universities should have a majority of external members, purportedly for their independence. This structure is also not uncommon at the individual Faculty level where Faculty Advisory Boards are comprised only of external members. Members of university councils have control, because they have a power of veto over the CEO. But they seldom use it.

The market power of students means that they are now the majority stakeholders in the corporate university. They exercise direct control over academics through student evaluations, indirect control through their demand for courses, and future control through the risk of litigation if they are not satisfied. But students also exercise implicit control through administrators, who have become the brokers of students. Administrators impose deadlines on academics that are for administrative convenience, not pedagogical importance. Administrators, who were originally subcontracted tasks, now extract the monopolistic rents that accrue to those tasks. Furthermore, administrators and management typically have similar objectives, the maximization of student satisfaction. The convergence of the objectives of both management and administrators to the utility of students is one of the most important, but most unwritten, stories of higher education. It is also the story of the decline in academe.

Zingales (2000) defined a firm as a set of implicit contracts. The most important implicit contract in the corporate university is the implicit contract between 
management and students. It is this contract which explains most of the conduct of the corporate university; the appointment of external members to the governing body, the rise and the excess of administration, the emergence of teaching and learning and the decay of physics and mathematics as disciplines, and the dilution of academic control. Academics in the old university governed the university and sub-contracted tasks to administrators. Academics in the corporate university are governed by external administrators, and are subcontracted by internal administrators. They no longer control the university.

The evolution of the corporate university began with government financial constraints, which led universities to privatise, to make external appointments, and to compete. This was the corporate takeover of the university. Academics often rejected this takeover, but they rejected it in silence. As a result of the takeover, control of the university transferred from the academics to the students who finance the university, and to the management who manage the academics. The evolution of the corporate university is now nearly complete. Only the shareholders are missing.

\section{The academic in the corporate university}

According to North (1990), institutions exist to minimise uncertainty. When universities changed, the uncertainty of academics changed. Their new uncertainties relate to student demand, managerialism, and restructuring. Academics who minimise risk follow four principles. They satisfy students, comply with management, segment between teaching and research, and are linear in their thinking. That is, they sub-contract to the corporate university.

To satisfy students, the academic entertains rather than teaches, uses PowerPoint rather than the whiteboard, informs and not questions, provides all course materials online and, above all, passes the students. The lecturer who does not provide all the solutions, who does not insert a joke, who asks questions that don't have answers will soon gravitate to the bottom of the student evaluations. Student evaluations are the measure of student satisfaction. They are now the measure of the teacher. All students are able to vote and to vote anonymously on their teachers. A student who scores $10 \%$ on the exam has an equal vote to the student who scores $95 \%$. Students are required to grade their teachers between 1 and 5 and the class average becomes a measure of the teacher's performance. If the teacher's mean score is less than some benchmark, the teacher's performance is unsatisfactory. If the teacher's mean score is above another benchmark, they win the teacher of the year award. There is no better measure of how students control the university than student evaluations. There are substantial incentives for teachers to dumb-down course material. There are also substantial incentives to increase grades. And grades have increased. Grade inflation is one of the hallmarks of the corporate university (Sabot \& WakemanLinn, 1991).

To comply with management, academics are bounded by administrative restrictions. Administration in universities is increasing in scale and scope, principally to ensure a standardised product. Administrative efficiency and pedagogical efficiency are usually not consonant. There are many examples where administrative efficiency comes first, and pedagogy second. Exam papers are now often set and submitted half way through a course. This is efficient for printing, but it means the teacher can not fully examine the latter part of the course nor easily extemporise in the later lectures. Necessarily, lectures must be pre-packaged, with no scope for experimentation. A second example relates to course materials. In business faculties, students often expect workbooks. And, for reasons similar to the printing of exams, workbooks must be prepared well in advance. There are strong incentives for the teacher to use prepackaged material associated with standardised textbooks and websites. The use of pre-packaged course materials designed at an Ivy League university is the type of outcome most students and university administrators want. But it is not an outcome 
consistent with academic values. The American Association of University Professors is opposed to having faculty members teach courses they do not create, as they believe this undermines their role at their own institution and, in particular, their scholarship. ${ }^{28} \mathrm{~A}$ third example relates to exam marking. Exams are now shorter so that more subjects can be examined within a fixed period. Exam grades also need to be submitted in a shorter time. There is an incentive for academics to set exams with standardised formats, using standardised questions from databanks. Multiple-choice questions are necessarily popular. But, in the workplace, the questions are rarely multiple-choice. Exams, workbooks and exam marking are examples where administrative efficiency is crowding out the freedom of teaching. The product is changing as a result.

The academic in the new university must segment teaching and research. Segmentation means that the time related to teaching should be minimised, and the time related to research maximised. Segmentation also means that student evaluations and the number of published papers have to be maximised. The efficient academic will use a standardised textbook and the same online lecture materials for a number of years; they will also produce many joint papers on a common theme each year. In the corporate university, the academic with a teaching evaluation of 4 is at least $30 \%$ better than an academic with an evaluation of 3 , and the academic who produces 10 papers is 10 times more productive than an academic producing one paper. This is the academic production line.

Academics have a choice; they can commit to the academic production line, or to the values of the old university. However, a commitment to old values is usually not rewarded. The academic who teaches students to think, or who researches long-term problems, can not expect high returns. The academic who speaks out will always earn negative returns. The risk for the academic is the risk in diverging too far from the vision of the corporate university. The academic must manage the trade-off between their values and the university's corporate values. But for the university to maintain its reputation it must also manage the trade-off between its corporate values and the values of the old university. In particular, the university must protect the role of the academic in the corporate university.

The academic can be protected in two ways. First, administrators and management should take account of academic values. Appointing administrators who currently teach and research is a solution. The demarcation of the staff of universities into those who administer and those who teach has created pools of ignorance on both sides of the demarcation line. When a Vice-Chancellor teaches a course, they encounter the problems that academics encounter. When a Faculty Dean is an academic, they know the problems that academics know. Appointing academics, who currently teach, to the hierarchy of the university, from the general manager to the Vice-Chancellor, underwrites academia.

Secondly, the balance of accountability between academics and management should change. Student evaluations render academics accountable to students, while management remain unaccountable. The students, who increasingly finance the university, are like shareholders of a firm. In a firm, it is the senior management, not the employees, who are accountable to the shareholders. The challenge is to construct a governing role for students that does not conflict with their status as a student, that is, does not affect their grades. The student Honor Court system, referred to in Section 3, is an example of a role that does not affect student grades. Another governing role which does not affect grades is to allow alumni to vote in the major restructuring decisions of the university; for example, the appointment of the Vice-Chancellor, privatisations, or the Oxford reforms. In contrast, student evaluations, which create incentives to inflate grades, conflict with the role of student as a student. Academia would be better protected if student evaluations were restricted. 
When universities became corporate universities, the constraints which defined the institution changed, and the role of the academic changed. Accountability replaced freedom, managerialism replaced innovation, and corporate values replaced academic values. However, if academics are too restricted by administrators, too accountable to students, or too standardised in their teaching and research, the product of the university will devalue. Insuring the academic role will insure the university. Without academic insurance, the corporate university, like academe, will decline.

\section{The decline in integrity}

The decline of academe has been correlated with a decline in academic integrity. Integrity refers to the consistency of decisions with a prescribed set of values; consistency across time, consistency across individuals and consistency across decisions. Integrity is one of those unobservable characteristics which can not be written into codes of ethics or into statutes. Rather it is determined by the thousands of decisions that an individual makes in their lifetime. In academia those decisions relate to the assessment and attribution of others, from marking an assignment to challenging the decision of a Vice-Chancellor. It is the cumulative effect of those decisions that determine an individual academic's integrity, and it is the aggregation of those decisions across a university that determines the integrity of the university.

With the evolution of the corporate university, academics and their universities have been challenged by the trade-off between the values of scholarship and the values of the market. When systemic values are changing, it is difficult to maintain the consistency which defines integrity. Necessarily, academics have assessed the risk of their decisions. Some academic decisions are more important than others, and some connote more risk than others. A decision to fail a student when they should have passed has more risk than a decision to award the student a $B$, when they should have attained an $\mathrm{A}$. A decision not to attribute a senior academic has more risk than a decision not to attribute a PhD student. And a decision to blow the whistle in a university is arguably the riskiest decision of all.

Risk is important to academics. A representative academic is typically risk averse; they trade-off the risk of a decision against their own values. And most choose to minimise the risk, rather than to unequivocally defend the values of scholarship. The risk aversion of academics partly explains why so many academics have been subordinated by the managerialism which dominates the modern corporate university. Few academics can remain true to values of scholarship when risk minimisation means they must maximise revenue. The academic who maintains a failure rate of $30 \%$ soon discovers the core values of the corporate university.

As a consequence, most academics have chosen to segment their academic lives. Administration, teaching and research are separable. Few academics will challenge the direction of a university and few will fail more students than prescribed by the university's bell curve. But in research, academics tend to assert their integrity, that is, preserve their intrinsic values. Their research determines their integrity. But there is no social sciences citation index for integrity and there are no Nobel Laureates of integrity. Integrity is not written into curriculum vitae nor assessed in performance appraisals. Integrity is unmeasurable and that which is unmeasurable is typically not priced.

The decline in integrity can only be observed through case studies and anecdotes. The decline in integrity is related to the conflict between the values of scholarship and the values of the market. In its extreme form, it appears in whistleblowing cases, such as those at the University of New South Wales, the University of New England and 
other Australian universities. Academics who attempt to assert the old values are often silenced through line management. The professor who resists managerialism often becomes the outsider. The frequency of whistleblowing cases in Australian higher education in the last 20 years is a testimony to the conflict of the values of the market and the values of scholarship. It is a test of educational integrity. And education is often the loser.

For the corporate university, that which was once hypothetical has become real. And universities neither have the scope nor scale of statutes to respond. The list of hypotheticals that have become real is nearly limitless. All involve the trade-off between the values of the market and the values of scholarship. For example, how does a university respond to a student who offers bribes to staff? If the student offers cash payments in exchange for higher grades, a significant penalty usually follows. But what if the student offers a consulting job to a professor; should there be a similar penalty? How should a university respond to a Department Head who assumes the role of an employer, managing their department as a profit and cost centre, hiring and firing on the basis of their own principles, rather than the principles of the university? How should a government respond to a university which offers monetary incentives to students to recruit other students? How should the academic community respond to research on pharmaceuticals which is paid for by a pharmaceutical company? In all cases, integrity is tested by the test between the values of the market and the values of scholarship. And usually, the values of the market prevail.

Universities have responded to perceptions of a decline in integrity by a reinforcement of codes of ethics and their statutes, and by other quality assurance mechanisms. But principally, this is a signalling exercise, a deterrent to obvious infractions. Revenue remains the bottom line for the corporate university.

\section{Conclusion}

This paper concerns one of the most important institutional changes of our lifetime, the corporatisation of universities. When institutions change, the constraints which define the values of the institution change. When universities became corporate universities, the values of the old university of truth, scholarship and freedom were replaced by monetary values. These new values defined education as a product, the university as a firm, and the university system as an industry.

When institutions change, the interactions between the members of the institution change. When universities became corporate universities, the interactions between academics and students, and academics and administrators, changed. There were new accountabilities. Academics were now accountable to students, administrators and management. The inversion of their role meant that academics increasingly had to trade-off innovation for managerialism, collegiality for competition, and freedom for accountability.

It was government financial constraints that changed universities. Universities are now required to educate, with fewer subsidies, more students to higher levels. Universities have become corporations mainly through competition, but also through external appointments and privatisation. Academics often rejected the corporate takeover, but rejected it in silence. Their uncertainty increased with restructuring; their collegiality decreased with managerialism. The risk-averse academic has become the academic of the production line, producing standardised teaching and research.

The convergence of the university towards the for-profit corporate university is now nearly complete. Only the shareholders are missing. The risk for the corporate university however is that, in their convergence towards the University of Phoenix 
model, universities may sacrifice too much scholarship, too much truth, and too much freedom. Their product will then be worthless and academic integrity an historical artefact.

\section{About the authors}

Kim Sawyer obtained a PhD in econometrics in 1981. His research interests include quantitative economics, finance and philosophy. $\mathrm{He}$ is an advocate for the rights of whistleblowers, especially in universities.

Associate Professor Jackie Johnson has a PhD in finance from the University of Western Australia. Current research concentrates on money laundering and the reactions of countries to ever tightening anti-money laundering legislation. As a consequence of the link between money laundering and offshore financial centres, the use of these centres by US corporations also became a topic of interest. The current paper was borne out of frustration with the changing university and the pressure put on academics to be quiet and conform, not only by their university but by their peers through the review process used by many journals.

Mark Holub completed his PhD in Finance at the University of Western Australia, where he is currently an Assistant Professor. His research interests include business ethics, taxation reform, and corporate financial policy. Mark teaches primarily in business finance and taxation.

\section{Endnotes}

${ }^{1}$ The authors acknowledge the generous comments of Emeritus Professor Richard Davis and an anonymous referee. The first author acknowledges the support of the Department of Accounting and Finance, University of Western Australia.

${ }^{2}$ This paper was originally presented at the $4^{\text {th }}$ Asia-Pacific Conference on Educational Integrity: Creating an Inclusive Approach, University of Wollongong, 2830 September 2009. It also appears in the Conference refereed proceedings and is reproduced here with the kind permission of the Editor, Professor Brian Martin.

${ }^{3}$ Department of Education and Science. (1991). Higher education: A new framework. HMSO, UK. White Paper.

${ }^{4}$ Department of Employment, Education and Training. (1988). Higher education: A policy statement. Canberra: Australian Government Publishing Service.

${ }^{5}$ Redefining universities is not new. The 1868 merger of the private College of California and the public Agricultural, Mining, and Mechanical Arts College formed the University of Berkeley, the oldest university in the University of California system.

${ }^{6}$ Marginson and Considine (2000) use the findings of 17 case studies of Australian universities to contend that the enterprise university is in a state of uncertainty generated by the discordance between its economic and academic functions. The university continuously reinvents itself because of this uncertainty.

${ }^{7}$ The core values of the University of Cambridge can be found in the statement of the University's mission and core values on their website at <http:// www.admin.cam.ac.uk/univ/mission.html>. Details taken from the website on December 14, 2006.

${ }^{8}$ University mottos typically reflect intangible values: Oxford University has "Lord is My Light"; Harvard University has "Veritas"; the London School of Economics has "To Know the Cause of Things"; and the University of Western Australia has "Seek Wisdom".

${ }^{9}$ University celebrates Sterling Library's 75th anniversary. (2005, September 2). Yale Bulletin \& Calendar, 34(2).

${ }^{10}$ The institutional change was substantial. Slaughter and Leslie (1997) argued that the changes in academic labour between 1970 and 1995 were as great as those associated with the industrial revolution during the last quarter of the 19th century. 
${ }^{11}$ The 2008 edition of the OECD publication Education at a Glance shows that $57 \%$ of school leavers in OECD countries went on to university in 2006, compared with $37 \%$ in 1995 . More than 2.9 million students are enrolled in foreign tertiary institutions, double the number in 1996 and a 50\% increase on 2000.

${ }^{12}$ The Group of Eight (G8) universities in Australia are considered to be the most prestigious and research-intensive universities. They are the University of New South Wales, University of Sydney, University of Queensland, University of Melbourne, University of Western Australia, University of Adelaide, Monash University and the Australian National University.

${ }^{13}$ 'Selected Higher Education Staff Statistics: Staff 2005' from Table 2: “Number of full-time and fractional full-time staff by current classification, 1995-2005", in Department of Education, Science \& Training, Australian Government.

${ }^{14}$ The 2001 Australian Senate Inquiry into Higher Education "Universities in Crisis" received 364 submissions. More than 100 were from individual academics, and many related to managerial problems.

${ }^{15}$ Quotations have been taken from Coady, T. (Ed.), (2000). Why universities matter: A conversation about values, means and directions (pp. 6-7). St. Leonards: Allen \& Unwin.

${ }^{16}$ Bruce Hall, a University of New South Wales professor, was accused of committing academic misconduct in medical research. The Vice-Chancellor's handling of the affair evoked criticism from inside and outside the university leading eventually to his resignation. (Sources: Controversy over Prof. Hall's scientific research continues: Australian Broadcasting Commission, AM, February 2, 2004; University of NSW Vice Chancellor to resign, Australian Broadcasting Commission, AM, April 8, 2004.)

${ }^{17}$ Van Biema, D. (2006). God versus science. Time, 168(20).

${ }^{18}$ Ministerial Order under Section 10 of the Tertiary Education Act 1993, dated July 14,1998

${ }^{19}$ Burrell, A. (2006, October 23). Brightest and best back UWA, The Australian Financial Review.

${ }^{20}$ Details of the University of Phoenix can be found on the university's website $<$ http://www.phoenix.edu/about_us/history>. Details taken from the website December 12, 2006.

${ }^{21}$ In terms of funding per equivalent full-time student adjusted for inflation, Australian government expenditure was at its lowest in 1987 before the Dawkins reforms. The 1996-97 Australian Federal budget further reduced operating grants to universities by $6 \%$ over four years, again as a precursor to reforms. It was 2001 before there was a substantial academic response to these funding cuts at the Senate Inquiry into Higher Education. See also Hywood, G. (2004, February 5). Where Cain is wrong about Melbourne Uni. The Age.

${ }^{22}$ Vinter, P. (2006, November 15). Dons back university reforms. Newsquest Media Group Newspapers.

${ }^{23} \mathrm{Dr}$ Hood, the Oxford Vice-Chancellor is currently pursuing his last option: a postal vote of all members of the Oxford congregation.

${ }^{24}$ Australia's higher education industry, for example, is now its second largest export earner generating more than $\mathrm{A} \$ 15$ billion of earnings. (Source: Morris, $\mathrm{S}$. (2006, October 9). Education a huge, and growing, economic boon. Australian Financial Review.)

${ }^{25}$ Reading confirms physics closure. (2006, November 20). BBC News.

${ }^{26}$ Royal Melbourne Institute of Technology Act 1992, Act No 45/1992, Part 2, Section 4(2).

${ }^{27}$ Committee of University Chairmen. (2004). Guide for Members of Higher Education Governing Bodies in the UK. Available on the CUC website at <http:// www.hefce.ac.uk/pubs/hefce/2004/04_40/>. Details taken from the website on November 20, 2006. 
${ }^{26}$ Carnevale, D. (2004, October 15). More professors teach by using other colleges' online courses. The Chronicle of Higher Education.

\section{References}

Anderson, D., Johnson, R., \& Saha, L. (2002). Changes in academic work: Implications for universities and work roles of academic staff. Canberra: Commonwealth of Australia.

Bessant, B. (1995). Corporate management and its penetration of university administration and government. Australian Universities' Review, 1, 59-62.

Biggs, J. (2002). Corporatised universities: An educational and cultural disaster. In J. Biggs \& R. Davis (Eds.), The subversion of Australian universities (Chapter 12, pp. 184-222). Wollongong: Fund for Intellectual Dissent.

Bishop, R. (2006). The global university. Theory, Culture \& Society 23(2-3), 563-566.

Davis, R. (2002). The unbalancing of Australian universities. Unpublished paper. Retrieved October 30, 2009, from http://www.uow.edu.au/ bmartin/dissent/ documents/sau/Davis.pdf

Department of Education and Science. (1991). Higher education: A new framework. UK: HMSO. (White Paper).

Department of Employment, Education and Training. (1988). Higher education: A policy statement. Canberra: Australian Government Publishing Service. (Dawkins White Paper).

Dobson, I. (2000). 'Them and us' - General and non-general staff in higher education. Journal of Higher Education Policy and Management, 22(2), 203-210.

Lewis, T., Marginson, S., \& Snyder, I. (2005). The network university? Technology, culture and organisational complexity in contemporary higher education. Higher Education Quarterly, 59(1), 56-75.

McNay, I. (1995). From the collegial academy to corporate enterprise: The changing cultures of universities. In T. Schuller (Ed.), The changing university? (pp. 105115). Buckingham: Open University Press.

Marginson, S., \& Considine, M. (2000). The enterprise university: Power, governance and reinvention in Australia. New York: Cambridge University Press.

North, D. (1990). Institutions: Institutional change and economic performance. Cambridge: Cambridge University Press.

Parker, M., \& Jary, D. (1995). The McUniversity: Organization, management and academic subjectivity. Organization, 2(2), 319-338.

Sabot, R., \& Wakeman-Lin, J. (1991). Grade inflation and course choice. Journal of Economic Perspectives, 5(1), 159-170.

Slaughter, S., \& Leslie, L. (1997). Academic capitalism: Politics, policies, and the entrepreneurial university. Baltimore: Johns Hopkins University Press.

Willmott, H. (1995). Managing the academics: Commodification and control in the development of university education in the U.K. Human Relations, 48(9), 9931027.

Winston, G. (1997). College costs: Subsidies, intuition, and policy. Paper presented to the National Commission on the Cost of Higher Education, Boston.

Zingales, L. (2000). In search of new foundations. The Journal of Finance, LV(4), 1623-1653. 